\title{
Evaluation of an aza-Michael approach for the synthesis of 3,3-dimethyl-2-aminocyclobutane-1-carboxylic acid
}

\author{
Florence Charnay-Pouget, ${ }^{\text {a }}$ Michael Frank, ${ }^{\text {b }}$ Jean-Pierre Baltaze, ${ }^{\text {a }}$ \\ Elisabeth Pereira, ${ }^{\text {a }}$ and David J. Aitken ${ }^{\mathrm{a}, *}$ \\ ${ }^{a}$ Université Paris-Sud, ICMMO (UMR 8182-CNRS), 15 rue Georges Clemenceau, \\ 91405 Orsay cedex, France \\ ${ }^{b}$ Clermont Université, Université Blaise Pascal, Laboratoire SEESIB (UMR 6504-CNRS), \\ 24 avenue des Landais, 63177 Aubière cedex, France \\ E-mail: david.aitken@u-psud.fr
}

This article is dedicated to Professor Ferenc Fülöp on the occasion of his $60^{\text {th }}$ birthday

\begin{abstract}
The aza-Michael addition reaction of a dibenzylic amide anion with $t$-butyl 3,3dimethylcyclobutene-1-carboxylate was investigated as a route to the title compound, a cyclic $\beta$ amino acid. In analogy with the known 5- and 6-membered ring homologues, the addition reaction proceeds smoothly, but with moderate diastereomeric and enantiomeric selectivities. The trans isomer of the title $\beta$-amino acid was obtained, for the first time, with a modest enantiomeric excess.
\end{abstract}

Keywords: Aza-Michael reaction, cyclobutenecarboxylate, $\beta$-amino acid, conjugate addition

\section{Introduction}

Alicyclic $\beta$-amino acids ( $\beta$-AAs) are of importance as building blocks for the synthesis of diverse molecular structures, and as such are attractive targets for chemical synthesis. ${ }^{1}$ In addition to their considerable pharmacological potential, ${ }^{2}$ they play a key role in the construction of $\beta$-peptides which are designed to adopt well-defined secondary structures. ${ }^{3}$ Oligomers of trans-2-aminocyclohexane-1-carboxylic acid (ACHC) have a tendency to adopt a 14-helical structure, ${ }^{4}$ while the oligomers of trans-2-aminocyclopentane-1-carboxylic acid (ACPC) ${ }^{5}$ or of trans-2-aminocyclobutane-1-carboxylic acid (ACBC) ${ }^{6}$ fold into a 12-helix. Recent developments in this area show that the overall folding preference of a $\beta$-peptide is influenced not only by the identity of the cyclic $\beta$-AA which provides the backbone, but also the presence of substituents on the peripheral parts of the alicycle. Thus, Fülöp and co-workers recently demonstrated that 
oligomers of a monoterpene-derived trans- $\beta$-AA, notionally a sterically challenged ACHC analog, preferred to adopt a 12-helix conformation in order to avoid long-range side-chain repulsions. ${ }^{7}$

In an effort to expand the set of available ring-substituted cyclic $\beta$-AAs, we envisaged the preparation of trans-3,3-dimethyl-2-aminocyclobutane-1-carboxylic acid 1 (Figure 1). This compound is a sterically-congested derivative of $\mathrm{ACBC}$, but can also be viewed as a conformationally constrained analog of the $\beta^{2}$-AA 2-aminomethyl-4-methylpentanoic acid 2 , or of the $\beta^{3}$-AA $\beta$-homovaline 3 , both of which have been incorporated into designed $\beta$-peptide sequences. ${ }^{8,9}$ Stereoselective routes to the parent ACBC have been established, ${ }^{10}$ but their extensions to a non-symmetrical target such as $\mathbf{1}$ are not evident. The gem-dimethyl-ACBC core can be prepared via a thermal [2+2] cycloaddition reaction between an $N, N$-dialkylenamine derivative of isobutyraldehyde and an acrylate ester; ${ }^{11}$ a major limitation is the imposition of a non-modifiable tertiary amine. Nonetheless, derivatives of $\mathbf{1}$ prepared in this way have been exploited periodically, notably as intermediates for the preparation of 3,3-dimethylcyclobutene1-carboxylate esters. ${ }^{12}$

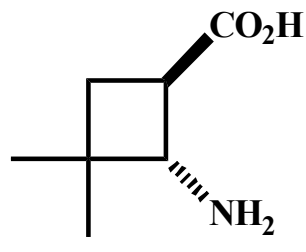

1

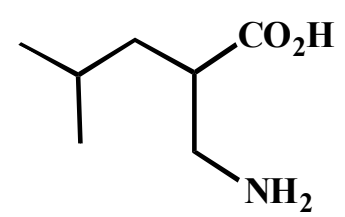

2

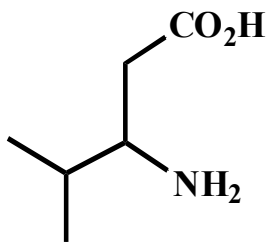

3

Figure 1. Structures of the target cyclobutane $\beta$-AA and related acyclic $\beta$-AAs.

We reasoned that a 3,3-dimethylcyclobutene-1-carboxylic ester might react in a conjugate addition manner with a nitrogen nucleophile which would be amenable to subsequent transformation into a primary amine. The aza-Michael reaction is a recognized general approach for the synthesis of $\beta$-AAs, and various asymmetric adaptations have been developped. ${ }^{13}$ One of the most productive approaches, developed by Davies, has been the conjugate addition of enantiomerically pure lithium amides to unsaturated esters. ${ }^{14}$ Indeed, asymmetric syntheses of cis-ACHC and cis-ACPC were described using this approach, and procedures for efficient epimerization were established, allowing access to trans-ACHC and trans-ACPC. ${ }^{15}$ Extensions of the methodology have been described to allow enantioselective preparation of cis and trans isomers of 3- or 5-alkyl-ACPCs. ${ }^{16}$ and 6 -alkyl-ACHCs, ${ }^{17}$ as well as the pyrrolidine and tetrahydrofuran analogs of ACPC. ${ }^{18}$ To date, however, the strategy has not been assessed as a route to smaller-ring $\beta$-AAs. We therefore studied the aza-Michael addition reaction as a route to the target molecule 3,3-dimethyl-ACBC. 


\section{Results and Discussion}

\section{Synthesis of the cyclobutene-1-carboxylic ester}

Previous work on the conjugate addition of lithium amides advocates the use of tert-butyl esters as the Michael acceptors, ${ }^{15,19}$ so our first task was to prepare tert-butyl 3,3-dimethylcyclobutene1-carboxylate 4. The corresponding methyl ester has previously been obtained by first preparing a methyl 2-dialkylaminocyclobutane-1-carboxylate via the thermal [2+2] cycloaddition reaction of methyl acrylate with an enamine obtained from isobutyraldehyde and dimethylamine, ${ }^{11,12 c, e}$ piperidine, ${ }^{12 \mathrm{~b}}$ or pyrrolidine, ${ }^{12 \mathrm{a}, \mathrm{d}}$ then conducting a Hofmann elimination on the adduct. We began our work adapting this process for the preparation of the tert-butyl ester 4 .

Enamine $\mathbf{5}$ was prepared from isobutyraldehyde and pyrrolidine ${ }^{20}$ and was heating with tert-butyl acrylate in refluxing acetonitrile for 5 days. The requisite tert-butyl 2-pyrrolidinocyclobutane-1carboxylate 6 was obtained in 91\% yield (Scheme 1). NMR analysis of this compound suggested that the thermal [2+2] cycloaddition had been completely stereoselective, since only one diastereomeric form of $\mathbf{6}$ was present; the correlations observed in a 2D NOESY experiment indicated that it was the trans isomer (Figure 2). Since the corresponding $N, N$-dibenzyl derivative $\mathbf{8}$ was the anticipated product of the planned subsequent aza-Michael addition reactions (vide infra), we attempted its preparation using the thermal [2+2] reaction. In the event, heating $t$-butyl acrylate with the enamine 7, obtained from iso-butyraldehyde and dibenzylamine, ${ }^{11 a}$ only gave a complex and intractable mixture of products (Scheme 1).
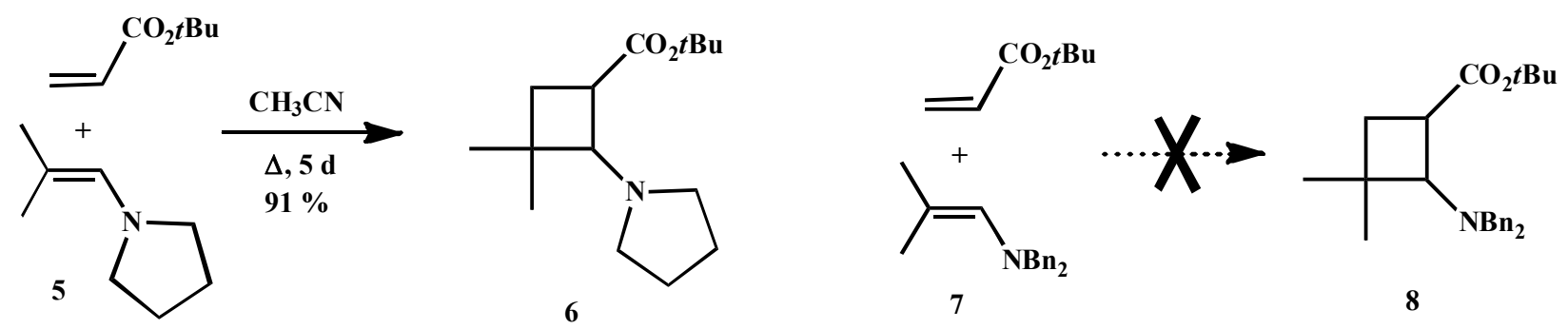

\section{Scheme 1}

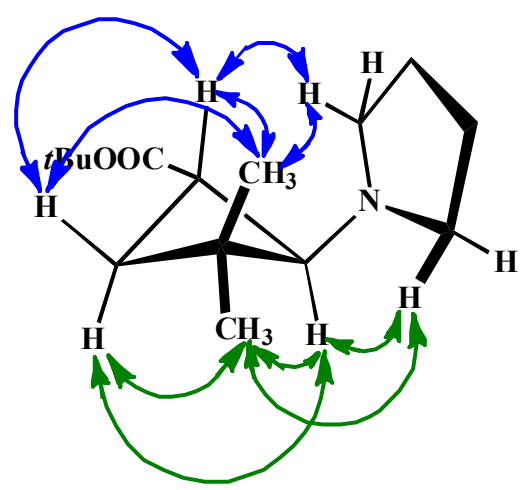

Figure 2. 2D NOESY interactions observed for compound $6\left(\mathrm{in}_{\mathrm{CDCl}}\right)$. 
Quaternization of the pyrrolidine adduct 6 with iodomethane followed by a potassium tertbutoxide-mediated Hofmann elimination gave the tert-butyl ester $\mathbf{4}$, accompanied by the carboxylic acid 9; this latter probably resulted from hydrolysis during the aqueous work-up. Indeed, using the original conditions (methyl tosylate then potassium hydroxide) from the literature work on the methyl ester, ${ }^{11 a}$ it was possible to obtain the acid $\mathbf{9}$ as the major product. In any event, re-esterification of the acid 9 could be achieved in high yield by treatment with isobutene in anhydrous acidic conditions.

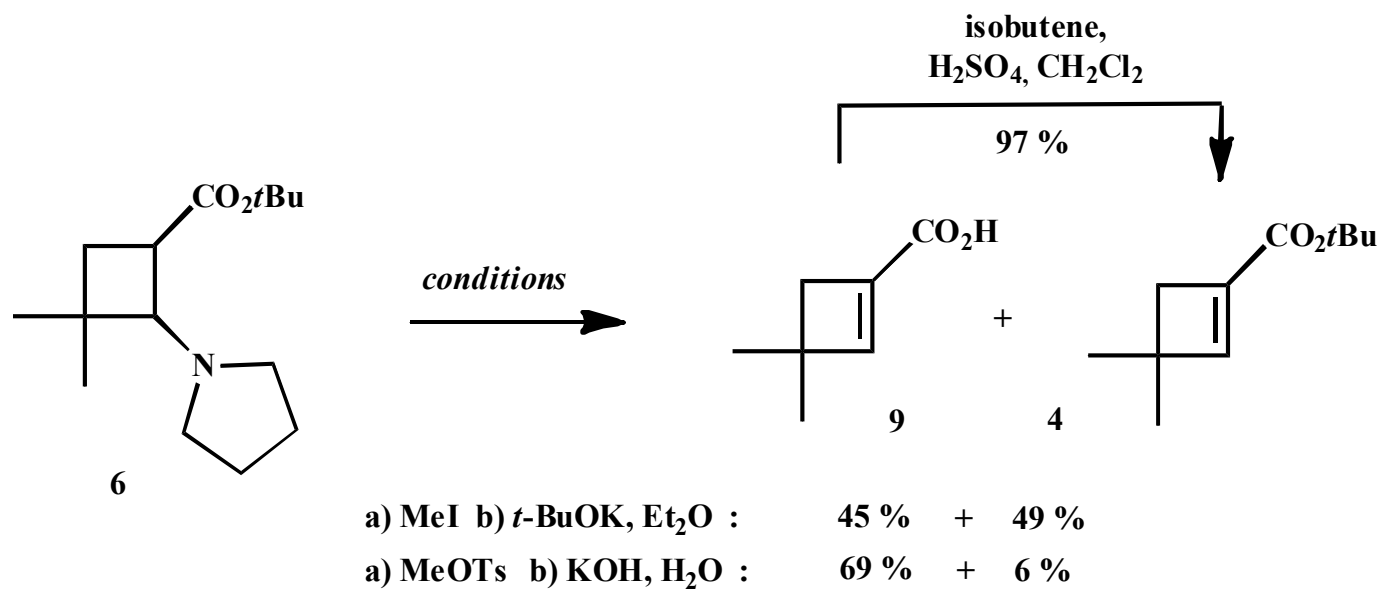

\section{Scheme 2}

\section{Michael Addition reactions}

The first series of experiments was conducted using a non-chiral lithium amide nucleophile derived from dibenzylamine (Scheme 3), in order to check the general feasibility of the Michael addition with acceptor 4 and to assess the diastereoselectivity of the reaction. Reactions were carried out by adding the nucleophile to a cold solution of 4 in THF, in analogy with Davies's procedures for the 5- and 6-membered ring homologues. ${ }^{15}$ After $2 \mathrm{~h}$ reaction time, the mixture was quenched with a proton source and the products worked up by standard procedures. Yields and diastereomeric excess are presented in Table 1.
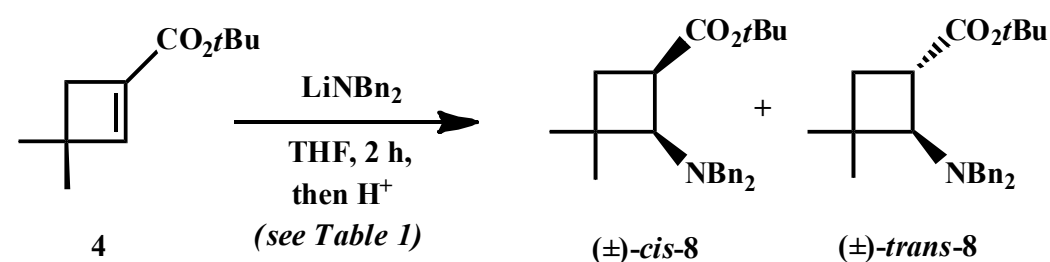

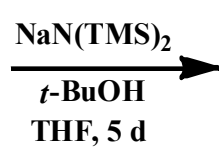

( \pm -cis-8

( \pm -trans-8

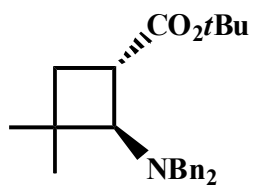

( \pm -trans-8

\section{Scheme 3}

The general reaction profile was for the formation of a mixture of cis and trans isomers of adduct 8, with the putative cis isomer dominating regardless of the proton source. The 
diastereomeric ratio was estimated from the integration of the benzylic proton signals in the ${ }^{1} \mathrm{H}$ NMR spectra of the inseparable mixtures. Reaction mixtures held at $-78^{\circ} \mathrm{C}$ gave low-to-average yield of 8 , with low diastereomeric excess. When the mixture was warmed to $-35^{\circ} \mathrm{C}$ during the $2 \mathrm{~h}$ reaction period before quenching, both the yield of $\mathbf{8}$ and the diastereomeric excess improved, with the latter reaching $70 \%$.

Table 1. Michael addition reactions of lithium dibenzylamide with unsaturated ester 4

\begin{tabular}{cccc}
\hline $\begin{array}{c}\text { Reaction } \\
\text { temperature }\left({ }^{\circ} \mathrm{C}\right)\end{array}$ & Proton source & $\begin{array}{c}\text { Total yield of } \mathbf{8} \\
(\%)\end{array}$ & $\begin{array}{c}\text { Estimated ratio } \\
\text { cis:trans }\end{array}$ \\
\hline-78 & $\mathrm{NH}_{4} \mathrm{Cl}$ & 32 & $50: 50$ \\
-78 & $\mathrm{TFA}$ & 59 & $65: 35$ \\
-78 & 2,6-di- $t$-butylphenol & 62 & $60: 40$ \\
-78 then -35 & $\mathrm{NH}_{4} \mathrm{Cl}$ & 71 & $85: 15$ \\
-78 then -35 & $\mathrm{TFA}$ & 80 & $80: 20$ \\
-78 then -35 & 2,6-di- $t$-butylphenol & 82 & $75: 25$ \\
\hline
\end{tabular}

By analogy with Davies's work on 5- and 6-membered Michael acceptors, ${ }^{15}$ the major component in samples of $\mathbf{8}$ was assumed to be the cis isomer. Davies's procedure for cis-to-trans isomerization was therefore applied to a 2:1 cis/trans mixture 8. Treatment of this sample with sodium hexamethyldisilazide in THF for 5 days provided a sample of $\mathbf{8}$, now composed of only the isomer for which the trans configuration had been assigned.

The second series of experiments was conducted using a chiral lithium amide nucleophile derived from $(S)$-( $\alpha$-methylbenzyl)benzylamine (Scheme 4$)$. In this case, the control of the configuration of the new stereogenic center at $\mathrm{C} 2$ of the adduct $\mathbf{1 0}$ is examined. Results are presented in Table 2 .

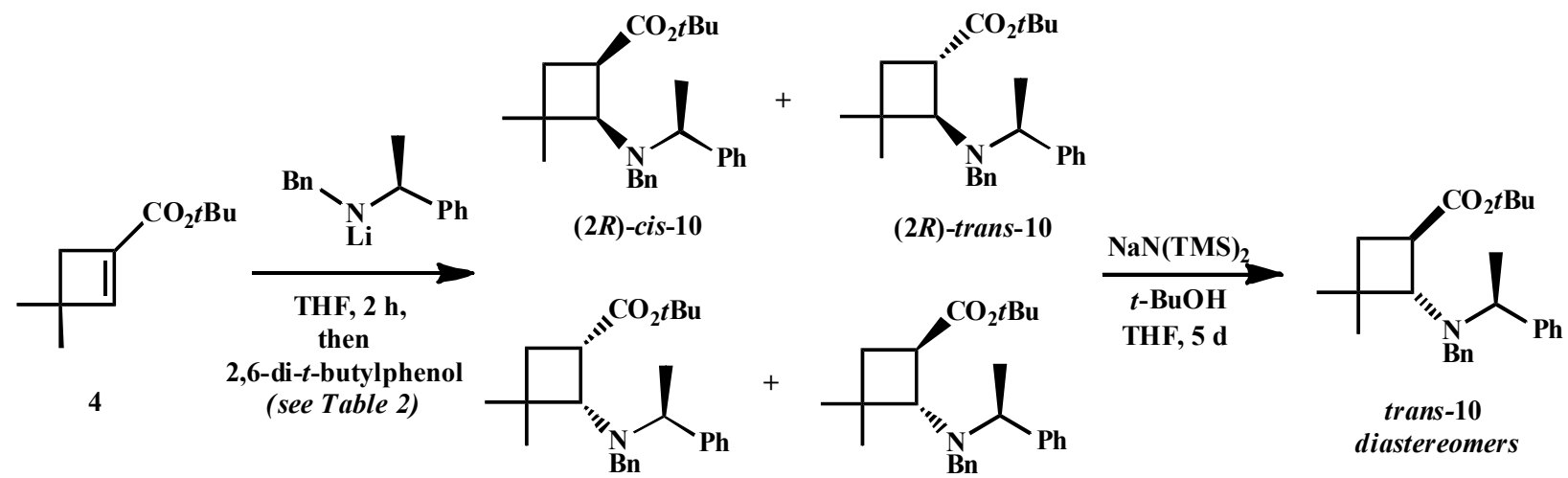

(2S)-cis-10

(2S)-trans-10

\section{Scheme 4}


Table 2. Michael addition reactions of chiral lithium amide with unsaturated ester 4.

\begin{tabular}{|c|c|c|c|c|}
\hline $\begin{array}{l}\text { Reaction } \\
\text { temperature } \\
\left({ }^{\circ} \mathrm{C}\right) \\
\end{array}$ & $\begin{array}{c}\text { Total } \\
\text { yield of } \\
\mathbf{1 0}(\%)\end{array}$ & $\begin{array}{l}\text { Estimated ratio } \\
(R) \text {-cis:(R)-trans: } \\
(S) \text {-cis:(S)-trans }\end{array}$ & $\begin{array}{l}\text { Estimated } \\
\text { ratio } \\
\text { cis:trans }\end{array}$ & $\begin{array}{c}\text { C2 stereoselectivity } \\
(R):(S)\end{array}$ \\
\hline-78 then -35 & 60 & $44: 12: 0: 44$ & $44: 56$ & $56: 44$ \\
\hline-78 & 72 & 50:31:0:19 & $50: 50$ & $81: 19$ \\
\hline-100 then -78 & 83 & $65: 12: 0: 23$ & $65: 35$ & $77: 23$ \\
\hline
\end{tabular}

In three experiments, conducted at different temperatures, three of the four possible diastereomers of $\mathbf{1 0}$ were detected in the ${ }^{1} \mathrm{H}$ NMR spectra. It was not possible to identify the components stereochemically at this stage, but when one product mixture with a 65:23:12 diastereomer ratio was submitted to the cis-to-trans epimerization protocol, two of the three diastereoisomers were recovered, this time in a 0:74:26 ratio, respectively. We deduced that the major component of the three initially-formed isomers of $\mathbf{1 0}$ had a cis configuration, and that the epimerization procedure had converted it into the trans isomer with the same $\mathrm{C} 2$ absolute configuration. This observation suggested that the cis/trans selectivity profile for the reaction in Scheme 4 was poor, as had been the case in the achiral version (Scheme 3). More importantly, we were able to deduce the $\mathrm{C} 2$ stereoselectivity of the initial attack of the nucleophile. When the reaction mixture was allowed to warm to $-35{ }^{\circ} \mathrm{C}$ after addition of the nucleophile, C2 stereoselectivity was very poor; however, keeping the reaction at $-78^{\circ} \mathrm{C}$ improved this situation somewhat to give a moderate stereochemical induction. Furthermore, the lower reaction temperature did not compromise the chemical yield of the $\beta$-amino ester. Davies had reported that the reaction of $t$-butyl cyclopentene-1-carboxylate with same chiral amide was conducted at $-95{ }^{\circ} \mathrm{C}$ in order to achieve high $\mathrm{C} 2$ stereoselectivity; ${ }^{15}$ in our case, the lower reaction temperature did not improve the moderate selectivity (nor the product yield).

The lack of control at $\mathrm{C} 2$ during the reaction in Scheme 4 can be rationalized in terms of steric hindrance. Davies showed that the preferred arrangement of conformation and stereofacial attack mode for chiral amides with cyclic and acyclic Michael acceptors corresponds to Figure $3 .^{21}$ In the case of a 3,3-dimethylcyclobutene-1-carboxylate substrate, such as $\mathbf{4}$, interference from the $\mathrm{C} 3$ methyl groups could destabilize this mode of attack. In the event, given the low stereochemical excesses observed, it is not possible to assert whether this mode persists at all, nor whether other modes become prevalent. 

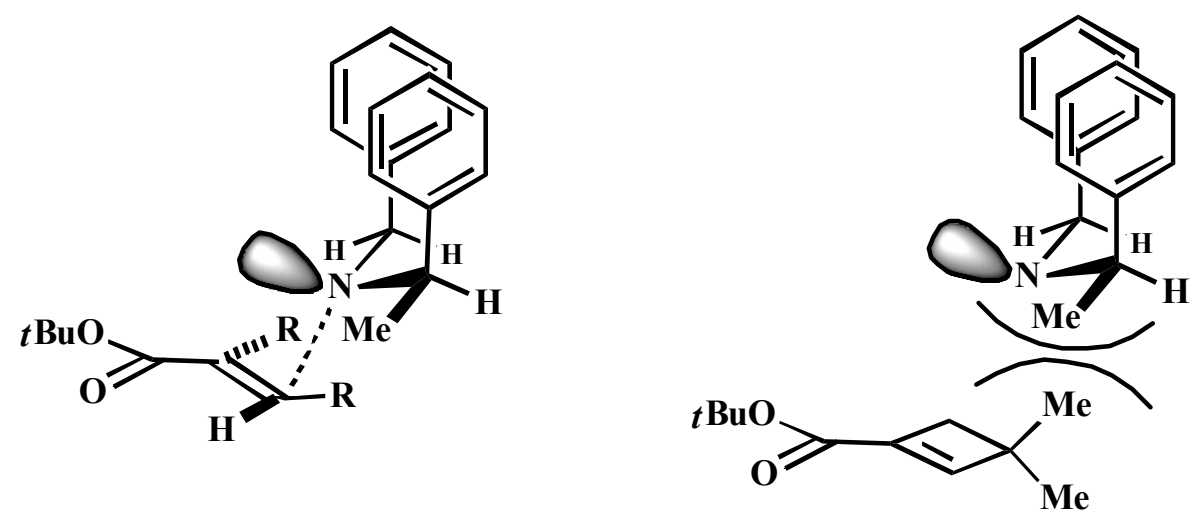

Figure 3. Left: Pictorial representation of the preferred approach of the amide nucleophile in its lowest energy conformation, leading to high C2 stereoselectivity. Right: Suggested steric repulsion which may disfavor this approach with the gem-3,3-dimethyl substrate 4 .

\section{Access to the title compound}

The first synthesis of the trans isomer of the title $\beta$-AA (1) was achieved (Scheme 5). The 3:1 mixture of the trans-10 diastereomers obtained from the epimerization procedure was hydrogenated in the presence of Pearlman's catalyst then the ester group cleaved with TFA. After purification on a cation exchange column, the target molecule was obtained in near quantitative yield. The trans configuration of $\mathbf{1}$ was confirmed by a 1D nOe NMR experiment (Figure 4). It was gratifying to note that the amine deprotection could be carried out without loss of material, which has been problematic in the past due to a push-pull ring-opening reaction. ${ }^{22}$ Indeed, we noted that a solution of trans -1 in $\mathrm{D}_{2} \mathrm{O}$ was stable for weeks at room temperature, whereas the corresponding ring-unsubstituted $\beta$-AA (trans-ACBC) visibly degrades in a few days in the same conditions. The enantiomeric excess (50\%) of trans-1, determined by analytical reverse-phase hplc analysis on a chiral column, was in agreement with the diastereomeric composition of the precursor trans-10. Given the modest degree of enantioselectivity, the absolute configuration of the major enantiomer was not examined.

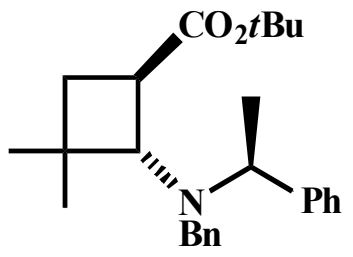

trans-10 a) $\mathrm{H}_{2}(3 \mathrm{~atm}), 20 \% \mathrm{Pd}(\mathrm{OH})_{2}-\mathrm{C}$, $\mathrm{AcOH}, 60^{\circ} \mathrm{C}$

b) TFA, rt, $24 \mathrm{~h}$

$$
99 \%
$$

diastereomers

\section{Scheme 5}

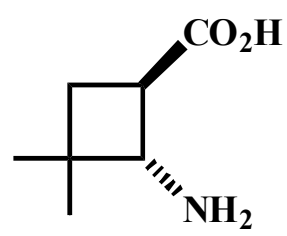

trans-1 


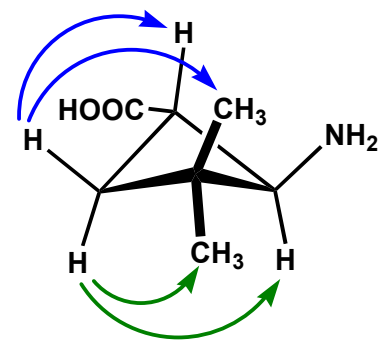

Figure 4. 1D nOe enhancements observed upon irradiation of each of the $\mathrm{C} 4$ protons of compound $\mathbf{1}$ (in $\mathrm{D}_{2} \mathrm{O}$ ).

\section{Conclusions}

This work shows that the conjugate addition reaction of a lithium amide with an appropriate Michael acceptor is a valid synthetic approach for the preparation of the trans isomer of the title compound. In the racemic series the reaction proceeds with good, but not complete cis selectivity, while an efficient epimerization protocol provides entry to the trans isomer. Transfer of the methodology to the asymmetric synthesis series does not provide the high levels of $\mathrm{C} 2$ stereocontrol which have previously been reported for 5- and 6-membered ring substrates - it is possible that the presence of the gem-dimethyl substituents at $\mathrm{C} 3$ interferes with the usually preferred stereofacial approach.

\section{Experimental Section}

General. Solvents were dried and purified according to standard procedures. Flash chromatography was performed on columns of silica gel $60(40-63 \mu \mathrm{m})$. Melting point ranges were taken on a Reichert microscope instrument. Optical rotation data were recorded on a Jasco DIP polarimeter. NMR spectra were recorded on a Bruker AC 400 instrument operating at 400 $\mathrm{MHz}\left({ }^{1} \mathrm{H}\right)$ or $100 \mathrm{MHz}\left({ }^{13} \mathrm{C}\right)$. Chemical shifts $\delta$ are reported in ppm with respect to TMS, using residual solvent signals as internal references. ${ }^{1} \mathrm{H}$ signal multiplicity abbreviations: $\mathrm{s}=$ singlet, $\mathrm{d}$ $=$ doublet, $\mathrm{t}=$ triplet, $\mathrm{q}=$ quartet, $\mathrm{m}=$ multiplet. Low resolution mass spectra $(\mathrm{MS})$ were obtained on a Hewlett-Packard HP 5989B instrument operating in chemical ionization (CI) mode using methane as the vector gas. High resolution mass spectra (HRMS) were obtained on a Bruker MicroTOFq instrument using positive-mode electrospray ionization (ESI).

tert-Butyl 2- $\mathrm{N}$-pyrrolidino-3,3-dimethylcyclobutane-1-carboxylate (6). Enamine 5 (14.1 g, $112.6 \mathrm{mmol})$ and tert-butyl acrylate $(14.4 \mathrm{~g}, 112.6 \mathrm{mmol})$ were dissolved in acetonitrile $(50 \mathrm{~mL})$, and the mixture refluxed under argon for 5 days. After cooling, the solvent was removed on a rotary evaporator, then the residual oil was purified by flash chromatography (petroleum 
ether/EtOAc, gradient from $80 / 20$ to $0 / 100$ ) to give the pyrrolidino ester $\mathbf{6}$ as a pale yellow oil (25.9 g, 91\%). Bp 100-105 ${ }^{\circ} \mathrm{C} / 0.5 \mathrm{~mm} .{ }^{1} \mathrm{H}-\mathrm{NMR}\left(\mathrm{CDCl}_{3}\right): \delta 0.90\left(\mathrm{~s}, 3 \mathrm{H}, \mathrm{CH}_{3}\right), 0.93(\mathrm{~s}, 3 \mathrm{H}$, $\left.\mathrm{CH}_{3}\right), 1.24(\mathrm{~s}, 9 \mathrm{H}, t \mathrm{Bu}), 1.47-1.50\left(\mathrm{~m}, 2 \mathrm{H}, \mathrm{CH}_{2}\right), 1.52-1.55\left(\mathrm{~m}, 4 \mathrm{H}, 2 \times \mathrm{CH}_{2}\right), 2.15-2.25(\mathrm{~m}, 4 \mathrm{H}$, $\left.2 \times \mathrm{CH}_{2}\right), 2.35(\mathrm{~d}, J=8.6 \mathrm{~Hz}, 1 \mathrm{H}, \mathrm{CHN}), 2.59(\mathrm{q}, J=9.0 \mathrm{~Hz}, 1 \mathrm{H}, \mathrm{CHCO}) .{ }^{13} \mathrm{C}-\mathrm{NMR}\left(\mathrm{CDCl}_{3}\right): \delta$ $21.9\left(\mathrm{CH}_{3}\right), 22.9$ (pyrrolidine $\left.\mathrm{CH}_{2}\right), 27.7\left(\mathrm{C}\left(\mathrm{CH}_{3}\right)_{3}\right), 29.3\left(\mathrm{CH}_{3}\right), 33.2(\mathrm{C}-4), 35.2(\mathrm{C}-3), 40.4(\mathrm{C}-$ 1), 52.0 (pyrrolidine $\left.\mathrm{CH}_{2}\right), 71.2(\mathrm{C}-2), 79.3\left(\mathrm{OC}\left(\mathrm{CH}_{3}\right)_{3}\right), 173.7$ (CO). HRMS (ESI): Calcd. for $\left[\mathrm{C}_{15} \mathrm{H}_{28} \mathrm{NO}_{2}+\mathrm{H}\right]^{+}:$254.2115. Found 254.2114.

\section{tert-Butyl 3,3-dimethylcyclobutene-1-carboxylate (4)}

Method A. Hoffman elimination from pyrrolidino ester (6). A mixture of pyrrolidino ester 6 (500 $\mathrm{mg} ; 1.97 \mathrm{mmol})$ and iodomethane $(532 \mathrm{mg} ; 3.75 \mathrm{mmol})$ in acetonitrile $(0.68 \mathrm{~mL})$ was stirred at $\mathrm{rt}$ for $14 \mathrm{~h}$. The mixture was concentrated in vacuo and the residue was dissolved in $\mathrm{Et}_{2} \mathrm{O}(3.15 \mathrm{~mL})$. A suspension of potassium tert-butoxide $(662 \mathrm{mg} ; 5.91 \mathrm{mmol})$ in $\mathrm{Et}_{2} \mathrm{O}(17 \mathrm{~mL})$ was added, and the mixture was refluxed for $4 \mathrm{~h}$. After cooling, $0.5 \mathrm{M} \mathrm{HCl}$ was added dropwise until $\mathrm{pH}=1$. The $\mathrm{Et}_{2} \mathrm{O}$ layer was collected and the aqueous phase was washed with more $\mathrm{Et}_{2} \mathrm{O}$ (2 $\times 5 \mathrm{~mL}$ ). Combined organic phases were dried over $\mathrm{MgSO}_{4}$ then the solvent was removed on a rotary evaporator to leave a yellow oil. Vacuum distillation $\left(55-60{ }^{\circ} \mathrm{C} / 1 \mathrm{mmHg}\right)$ of this oil gave the desired $t$-butyl ester 4 (176 mg; 49\%). The solid residue was identified as the known ${ }^{11 \mathrm{a}}$ carboxylic acid 9 (111 $\mathrm{mg} ; 45 \%)$.

Ester (4). Colorless oil. ${ }^{1} \mathrm{H}-\mathrm{NMR}\left(\mathrm{CDCl}_{3}\right): \delta 1.14\left(\mathrm{~s}, 6 \mathrm{H}, 2 \times \mathrm{CH}_{3}\right), 1.48(\mathrm{~s}, 9 \mathrm{H}, t \mathrm{Bu}), 2.38(\mathrm{~s}, 2 \mathrm{H}$, $\left.\mathrm{CH}_{2}\right), 6.72(\mathrm{~s}, 1 \mathrm{H}, \mathrm{CH}) .{ }^{13} \mathrm{C}-\mathrm{NMR}\left(\mathrm{CDCl}_{3}\right): \delta 25.3\left(2 \times \mathrm{CH}_{3}\right), 27.7(t \mathrm{Bu}), 40.0(\mathrm{C}-3), 42.4(\mathrm{C}-4)$, $79.8\left(\underline{\mathrm{C}}\left(\mathrm{CH}_{3}\right)_{3}\right), 135.9 \quad(\mathrm{C}-1), 153.6 \quad(\mathrm{C}-2), 162.5 \quad(\mathrm{C}=\mathrm{O}) . \quad H R M S \quad(\mathrm{ESI})$ ) Calcd. for $\left[\mathrm{C}_{11} \mathrm{H}_{18} \mathrm{NaO}_{2}+\mathrm{Na}\right]^{+}:$205.1199. Found 205.1194.

Acid 9: white solid. $\mathrm{Mp}=69-71{ }^{\circ} \mathrm{C}$ (pentane) $\left(\right.$ lit. $\left.{ }^{11 \mathrm{a}} 71.5-72.5{ }^{\circ} \mathrm{C}\right) .{ }^{1} \mathrm{H}-\mathrm{NMR}\left(\mathrm{CDCl}_{3}\right): \delta 1.26(\mathrm{~s}$, $\left.6 \mathrm{H}, \mathrm{CH}_{3}\right), 2.44\left(\mathrm{~s}, 2 \mathrm{H}, \mathrm{CH}_{2}\right), 7.00(\mathrm{~s}, 1 \mathrm{H}, \mathrm{H}-2), 12.20$ (br s, $\left.1 \mathrm{H}, \mathrm{COOH}\right) .{ }^{13} \mathrm{C}-\mathrm{NMR}\left(\mathrm{CDCl}_{3}\right): \delta$ $25.3\left(2 \times \mathrm{CH}_{3}\right), 41.3(\mathrm{C}-3), 42.4(\mathrm{C}-4), 134.0(\mathrm{C}-1), 158.8(\mathrm{C}-2), 168.5(\mathrm{C}=\mathrm{O})$.

Method B. Esterification of carboxylic acid (9). Carboxylic acid 9 (4.79 g, $38 \mathrm{mmol}$ ) was dissolved in $\mathrm{CH}_{2} \mathrm{Cl}_{2}(40 \mathrm{~mL})$ and the solution cooled to $-78{ }^{\circ} \mathrm{C}$. Isobutene $(9 \mathrm{~mL})$ was added by cannula, followed by sulphuric acid $(0.3 \mathrm{~mL})$. The mixture was stirred at $-78{ }^{\circ} \mathrm{C}$ for $1 \mathrm{~h}$ then at $-25{ }^{\circ} \mathrm{C}$ overnight. A saturated aqueous solution of $\mathrm{NaHCO}_{3}$ was added until gas evolution stopped, then the organic phase was collected. The remaining aqueous solution was extracted with $\mathrm{Et}_{2} \mathrm{O}(3 \times 10 \mathrm{~mL})$. Combined organic phases were washed with brine $(2 \times 10 \mathrm{~mL})$ then dried over $\mathrm{MgSO}_{4}$. The solvent was removed on a rotary evaporator, and the residue was purified by vacuum distillation as above to give the $t$-butyl ester 4 as a colorless oil $(1.78 \mathrm{~g}, 97 \%)$.

\section{Conjugate addition reaction of lithium $N, N$-dibenzylamide with ester (4)}

A solution of $N, N$-dibenzylamine $(3.2 \mathrm{mmol})$ in THF at $0{ }^{\circ} \mathrm{C}$ was treated with $n$-BuLi solution in hexane $(3 \mathrm{mmol})$. The resulting red solution was cooled to the desired reaction temperature $(-95$ or $\left.-78{ }^{\circ} \mathrm{C}\right)$. A solution of ester $4(1.0 \mathrm{mmol})$ in THF was added and the mixture was stirred for 2 $\mathrm{h}$ at the temperature indicated. The reaction was then quenched by addition of 2,6-di-tertbutylphenol $(6 \mathrm{mmol})$ (or another proton source) then allowed to return to $\mathrm{rt}$. The crude product 
mixture was concentrated on a rotary evaporation, then partitioned between $\mathrm{Et}_{2} \mathrm{O}$ and brine. The organic phase was dried over $\mathrm{MgSO}_{4}$ and the solvent removed on a rotary evaporator. NMR analysis was performed at this stage in order to determine diastereomer ratios, then the crude product was purified by flash chromatography (cyclohexane/EtOAc, 50/1), to give an inseparable mixture of amino esters $\operatorname{cis} \mathbf{- 8}$ and trans $\mathbf{- 8}$ (ratio approx. 3:1). Within this mixture, the following data are attributed to the major cis-8 isomer: ${ }^{1} \mathrm{H}-\mathrm{NMR}\left(\mathrm{CDCl}_{3}\right): \delta 1.06\left(\mathrm{~s}, 3 \mathrm{H}, \mathrm{CH}_{3}\right)$, $1.44\left(\mathrm{~s}, 3 \mathrm{H}, \mathrm{CH}_{3}\right), 1.56(\mathrm{~s}, 9 \mathrm{H}, t \mathrm{Bu}), 1.73\left(\mathrm{dd}, J=11.4 \mathrm{~Hz}, J=4.4 \mathrm{~Hz}, 1 \mathrm{H}, \mathrm{CH}_{2}\right), 2.08(\mathrm{dd}, J=$ $\left.11.4 \mathrm{~Hz}, J=8.7 \mathrm{~Hz}, 1 \mathrm{H}, \mathrm{CH}_{2}\right), 3.25$ (d, $\left.J=9.1 \mathrm{~Hz}, 1 \mathrm{H}, \mathrm{H}-1\right), 3.36$ (td, $J=9.0 \mathrm{~Hz}, J=3.9 \mathrm{~Hz}$, $1 \mathrm{H}, \mathrm{H}-2), 3.52\left(\mathrm{~d}, J=14.7 \mathrm{~Hz}, 2 \mathrm{H}, \mathrm{BnCH}_{2}\right), 3.79\left(\mathrm{~d}, J=14.7 \mathrm{~Hz}, 2 \mathrm{H}, \mathrm{BnCH}_{2}\right), 7.25-7.31(\mathrm{~m}$, $10 \mathrm{H}, \mathrm{ArH}) .{ }^{13} \mathrm{C}-\mathrm{NMR}\left(\mathrm{CDCl}_{3}\right): \delta 22.5\left(\mathrm{CH}_{3}\right), 28.1(t \mathrm{Bu}), 32.0\left(\mathrm{CH}_{3}\right), 33.9\left(\mathrm{CH}_{2}\right.$ cycle $), 38.8(\mathrm{C}-$ 3), $40.7(\mathrm{C}-1), 52.3\left(\mathrm{NCH}_{2}\right), 65.8(\mathrm{~d}, \mathrm{C}-2), 80.3\left(\underline{\mathrm{C}}\left(\mathrm{CH}_{3}\right)_{3}\right), 126.7(p-\mathrm{C}), 128.0(\mathrm{Ar}-\mathrm{C}-\mathrm{H}), 129.3$ (Ar-C-H), 137.7 (Ar-C), $174.1(\mathrm{C}=\mathrm{O})$.

tert-Butyl $( \pm)-$ trans-2-( $N, N$-dibenzylamino)-3,3-dimethylcyclobutane-1-carboxylate (trans8).

A solution of $t$ - $\mathrm{BuOH}(520 \mathrm{mg}, 7.0 \mathrm{mmol})$ in THF $(15 \mathrm{~mL})$ was cooled to $0{ }^{\circ} \mathrm{C}$ and a solution of sodium hexamethyldisilazide in THF (2 M, $1.5 \mathrm{~mL} ; 3.0 \mathrm{mmol})$ was added. This mixture was stirred for $15 \mathrm{~min}$, then a solution of the $\mathbf{8}$ diastereomer mixture described above $(301 \mathrm{mg}, 0.8$ mmol) in THF $(5 \mathrm{~mL})$ was added. The black solution was stirred for 5 days. The solvent was removed on a rotary evaporator, and the residue was partitioned between $\mathrm{Et}_{2} \mathrm{O}$ and brine. The organic phase was dried over $\mathrm{MgSO}_{4}$ and the solvent removed on a rotary evaporator to leave the crude product as a brown oil. NMR analysis was performed at this stage to establish that only one diastereomer was present (which had been the minor component in the starting sample). Purification by flash chromatography (cyclohexane/EtOAc, 50/1) furnished trans-8 (242 mg, 80 $\%)$ as a paste-like solid. ${ }^{1} \mathrm{H}-\mathrm{NMR}\left(\mathrm{CDCl}_{3}\right): \delta 1.16\left(\mathrm{~s}, 3 \mathrm{H}, \mathrm{CH}_{3}\right), 1.30\left(\mathrm{~s}, 3 \mathrm{H}, \mathrm{CH}_{3}\right), 1.41(\mathrm{~s}, 9 \mathrm{H}$, $t \mathrm{Bu}), 1.53\left(\mathrm{t}, J=10.2 \mathrm{~Hz}, 1 \mathrm{H}, \mathrm{CH}_{2}\right), 1.73\left(\mathrm{t}, J=10.1 \mathrm{~Hz}, 1 \mathrm{H}, \mathrm{CH}_{2}\right), 2.76(\mathrm{q}, J=9.5 \mathrm{~Hz}, 1 \mathrm{H}, \mathrm{H}-$ 1), 3.27 (d, $J=9.1 \mathrm{~Hz}, 1 \mathrm{H}, \mathrm{H}-2), 3.48$ (d, $\left.J=14.3 \mathrm{~Hz}, 2 \mathrm{H}, \mathrm{BnCH}_{2}\right), 3.69$ (d, $J=14.3 \mathrm{~Hz}, 2 \mathrm{H}$, $\left.\mathrm{BnCH}_{2}\right), 7.20$ (t, $\left.J=7.2 \mathrm{~Hz}, 2 \mathrm{H}, \mathrm{Ar}-\mathrm{H}\right), 7.25-7.31$ (m, 4H, ArH), 7.37 (d, $\left.J=7.4 \mathrm{~Hz}, 4 \mathrm{H}, \mathrm{ArH}\right)$. ${ }^{13} \mathrm{C}-\mathrm{NMR}\left(\mathrm{CDCl}_{3}\right): \delta 22.5\left(\mathrm{CH}_{3}\right), 28.1(t \mathrm{Bu}), 30.3\left(\mathrm{CH}_{3}\right), 34.1\left(\mathrm{CH}_{2}\right.$ cycle $), 36.9(\mathrm{C}-3), 40.2(\mathrm{C}-$ 1), $56.0\left(\mathrm{NCH}_{2}\right), 68.5(\mathrm{C}-2), 79.9\left(\underline{\mathrm{C}}\left(\mathrm{CH}_{3}\right)_{3}\right), 126.7(p-\mathrm{C}), 128.1$ (Ar-C), 128.8 (Ar-C), 140.0 (ipso-C), $174.4(\mathrm{C}=\mathrm{O})$. MS (CI) $m / z=380[\mathrm{M}+\mathrm{H}]^{+}$. Anal. Calcd. for $\mathrm{C}_{25} \mathrm{H}_{33} \mathrm{NO}_{2}(\%)$ : C, 79.10; H, 8.77; N, 3.69. Found: C, 79.01; H, 8.81; N, 3.62.

\section{Conjugate addition reaction of lithium $(S)$ - $N$-benzyl- $N$ - $\alpha$-methylbenzylamide with ester (4)}

A solution of $(S)-N$ - $\alpha$-methylbenzyl- $N$-benzylamine $(3.2 \mathrm{mmol})$ in THF at $0{ }^{\circ} \mathrm{C}$ was treated with $n$-BuLi solution in hexane $(3 \mathrm{mmol})$. The resulting red solution was cooled to the desired reaction temperature $\left(-95\right.$ or $\left.-78^{\circ} \mathrm{C}\right)$. A solution of ester $4(1.0 \mathrm{mmol})$ in THF was added and the mixture was stirred for $2 \mathrm{~h}$ at the temperature indicated. The reaction was then quenched by addition of 2,6-di-tert-butylphenol $(6 \mathrm{mmol}$ ) (or another proton source) then allowed to return to rt. The crude product mixture was concentrated on a rotary evaporation, then partitioned between ether and brine. The organic phase was dried over $\mathrm{MgSO}_{4}$ and the solvent removed on a rotary 
evaporator. NMR analysis was performed at this stage in order to determine diastereomer ratios, then the crude product was purified by flash chromatography (cyclohexane/EtOAc, 50/1) to give an inseparable mixture of three diastereomers of amino ester 10. The relative proportions were assessed from the benzylic signals in the ${ }^{1} \mathrm{H}-\mathrm{NMR}$ spectrum (ratio approx. 3:1). Further interpretation or assignment of spectral data was not feasible.

tert-Butyl trans-2-[(S)- $N$ - $\alpha$-methylbenzyl- $N$-benzylamino) $]-3,3-$ dimethylcyclobutane-1carboxylate (trans-10)

A solution of $t$ - BuOH $(2.22 \mathrm{~g}, 30 \mathrm{mmol})$ in THF $(60 \mathrm{~mL})$ was cooled to $0{ }^{\circ} \mathrm{C}$ and a solution of sodium hexamethyldisilazide in THF $(2 \mathrm{M}, 7 \mathrm{~mL} ; 14 \mathrm{mmol})$ was added. The brown solution was stirred for $15 \mathrm{~min}$ then a solution of amino ester $\mathbf{1 0}(1.45 \mathrm{~g}, 3.7 \mathrm{mmol}$, as a 65:23:12 diastereomeric mixture) in THF $(15 \mathrm{~mL})$ was added. The black solution was stirred for 5 days. The solvent was removed on a rotary evaporator, and the residue was partitioned between $\mathrm{Et}_{2} \mathrm{O}$ and brine. The organic phase was dried over $\mathrm{MgSO}_{4}$ and the solvent removed on a rotary evaporator to leave the crude product as a brown oil (1.48 g). NMR analysis was performed at this stage to establish that only two diastereomers remained (those which had been the second and third most abundant in the starting sample). Purification by flash chromatography (cyclohexane/EtOAc, 50/1) furnished an inseparable mixture of two trans-10 diastereomers (1.39 g, $96 \%$ ). Mp: $58-76{ }^{\circ} \mathrm{C}$. MS (CI) $m / z=394[\mathrm{M}+\mathrm{H}]^{+}$. Anal. Calcd. for $\mathrm{C}_{26} \mathrm{H}_{35} \mathrm{NO}_{2}$ (\%): C, 79.35 ; H: 8.96; N, 3.56. Found: C, 79.19; H, 8.88; N: 3.54.

The following data are attributed to the major trans-10 isomer in the mixture. ${ }^{1} \mathrm{H}-\mathrm{NMR}$ $\left(\mathrm{CDCl}_{3}\right): \delta 1.27\left(\mathrm{~s}, 3 \mathrm{H}, \mathrm{CH}_{3}\right), 1.39\left(\mathrm{~s}, 3 \mathrm{H}, \mathrm{CH}_{3}\right), 1.41(\mathrm{~s}, 9 \mathrm{H}, t \mathrm{Bu}), 1.42-1.60\left(\mathrm{~m}, 4 \mathrm{H}, \mathrm{CH}_{3}\right.$, $\mathrm{CH}_{2}$ ), 1.74 (t, $\left.J=10.1 \mathrm{~Hz}, 1 \mathrm{H}, \mathrm{CH}_{2}\right), 2.55$ (q, $\left.J=9.4 \mathrm{~Hz}, 1 \mathrm{H}, \mathrm{H}-1\right), 3.50(\mathrm{~d}, J=15.0 \mathrm{~Hz}, 1 \mathrm{H}$, $\mathrm{CH}_{2}$ ), 3.61 (d, $\left.J=9.2 \mathrm{~Hz}, 1 \mathrm{H}, \mathrm{CHN}\right), 3.69$ (d, $\left.J=15.0 \mathrm{~Hz}, 1 \mathrm{H}, \mathrm{CH}_{2}\right), 4.08$ (q, $J=6.7 \mathrm{~Hz}, 1 \mathrm{H}$, $\left.\mathrm{CHCH}_{3}\right), 7.15-7.40(\mathrm{~m}, 8 \mathrm{H}, \mathrm{ArH}), 7.63(\mathrm{~d}, J=7.7 \mathrm{~Hz}, 2 \mathrm{H}, \mathrm{ArH}) .{ }^{13} \mathrm{C}-\mathrm{NMR}\left(\mathrm{CDCl}_{3}\right): \delta 9.7$

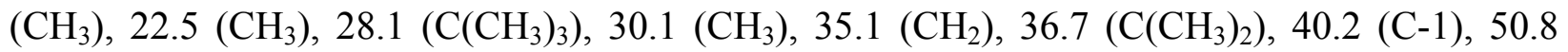
$(\mathrm{CHN}), 56.3\left(\mathrm{NCH}_{2}\right), 65.3(\mathrm{C}-2), 79.6\left(\mathrm{C}_{\left.\left(\mathrm{CH}_{3}\right)_{3}\right),}\right)$ 126.2, 126.2, 126.6, 126.6, 126.9, 127.4, 127.6, 127.7, 127.9, 127.1, 128.2, 128.3, 128.7, (Ar-CH, overlapping with minor isomer signals), 142.0 (Ar-C), 143.8 (Ar-C), $1742(\mathrm{C}=\mathrm{O})$.

The following data are attributed to the minor trans-10 isomer in the mixture. ${ }^{1} \mathrm{H}-\mathrm{NMR}$ $\left(\mathrm{CDCl}_{3}\right): \delta 0.88\left(\mathrm{~s}, 3 \mathrm{H}, \mathrm{CH}_{3}\right), 1.23\left(\mathrm{~s}, 3 \mathrm{H}, \mathrm{CH}_{3}\right), 1.38(\mathrm{~s}, 9 \mathrm{H}, t \mathrm{Bu}), 2.97(\mathrm{q}, J=9.4 \mathrm{~Hz}, 1 \mathrm{H}, \mathrm{H}-1)$, $3.38(\mathrm{~d}, J=9.3 \mathrm{~Hz}, 1 \mathrm{H}, \mathrm{CHN}), 3.78\left(\mathrm{~d}, J=13.8 \mathrm{~Hz}, 1 \mathrm{H}, \mathrm{CNCH}_{2}\right), 3.85(\mathrm{~d}, J=12.7 \mathrm{~Hz}, 1 \mathrm{H}$, $\left.\mathrm{NCH}_{2}\right), 3.99\left(\mathrm{q}, J=6.9 \mathrm{~Hz}, 1 \mathrm{H}, \mathrm{CHCH}_{3}\right)$, other signals masked. ${ }^{13} \mathrm{C}-\mathrm{NMR}\left(\mathrm{CDCl}_{3}\right): \delta 15.0$

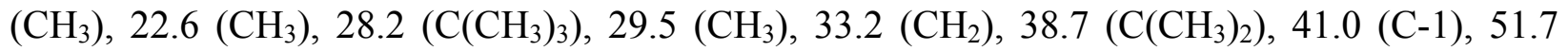
$(\mathrm{CHN}), 56.2\left(\mathrm{NCH}_{2}\right), 141.9$ (Ar-C), 143.1 (Ar-C), other signals masked.

\section{trans-2-Amino-3,3-dimethylcyclobutane-1-carboxylic acid (trans-1)}

A mixture of diastereomers of amino ester trans-10 (190 mg, $0.48 \mathrm{mmol}$, dr $\sim 3: 1)$ was dissolved in glacial acetic acid $(25 \mathrm{~mL})$ and a spatula tip of $\mathrm{Pd}(\mathrm{OH})_{2}-\mathrm{C}$ was added. The mixture was Parr hydrogenated ( $3 \mathrm{~atm})$ at $60{ }^{\circ} \mathrm{C}$ for $20 \mathrm{~h}$. The mixture was cooled and filtered through Celite, with the solid residue being washed through with $\mathrm{MeOH}$. The solvents were removed on a rotary 
evaporator. The residue was partitioned between $\mathrm{CH}_{2} \mathrm{Cl}_{2}$ and a saturated aqueous solution of $\mathrm{NaHCO}_{3}$. The organic phase was collected, dried over $\mathrm{MgSO}_{4}$, then the solvent was removed on a rotary evaporator to leave a mixture of a yellow oil and some solid material $(126 \mathrm{mg})$. To this residue was added TFA $(4 \mathrm{~mL})$, and the resulting solution was stirred at $\mathrm{rt}$ for $24 \mathrm{~h}$. The solvent was removed on a rotary evaporator, and the residue was treated with ethereal $\mathrm{HCl}$ and $\mathrm{MeOH}$, then evaporated to dryness on a rotary evaporator. The residue was partitioned between $0.5 \mathrm{M}$ $\mathrm{HCl}(5 \mathrm{~mL})$ and $\mathrm{Et}_{2} \mathrm{O}(5 \mathrm{~mL})$. The aqueous phase was collected and reduced to a volume of 2 $\mathrm{mL}$, then applied to a column of $\mathrm{H}^{+}$ion exchange resin (Dowex 50X8 20-50 mesh). After elution with $1 \mathrm{M} \mathrm{NH}_{4} \mathrm{OH}$, and evaporation of appropriate fractions, the product was obtained as a sticky solid, which was washed once with ether to give the title $\beta$-AA trans -1 (70 mg, $99 \%$ ). Mp: 153-157 ${ }^{\circ} \mathrm{C} .[\alpha]_{\mathrm{D}}^{20}+23.7\left(c 0.54, \mathrm{H}_{2} \mathrm{O}\right) .{ }^{1} \mathrm{H}-\mathrm{NMR}\left(\mathrm{D}_{2} \mathrm{O}\right): \delta 0.94\left(\mathrm{~s}, 3 \mathrm{H}, \mathrm{CH}_{3}\right), 0.98\left(\mathrm{~s}, 3 \mathrm{H}, \mathrm{CH}_{3}\right)$, $1.54\left(\mathrm{t}, J=10.3 \mathrm{~Hz}, 1 \mathrm{H}, \mathrm{CH}_{2}\right), 1.84$ (t, $\left.J=10.7 \mathrm{~Hz}, 1 \mathrm{H}, \mathrm{CH}_{2}\right), 2.85$ (q, $J=9.5 \mathrm{~Hz}, 1 \mathrm{H}, \mathrm{CHCO}$ ), $3.39(\mathrm{~d}, J=8.6 \mathrm{~Hz}, 1 \mathrm{H}, \mathrm{CHN}) .{ }^{13} \mathrm{C}-\mathrm{NMR}\left(\mathrm{D}_{2} \mathrm{O}\right): \delta 23.2\left(\mathrm{CH}_{3}\right), 30.1\left(\mathrm{CH}_{3}\right), 30.4\left(\underline{\mathrm{C}}\left(\mathrm{CH}_{3}\right)_{2}\right), 37.1$ $\left(\mathrm{CH}_{2}\right), 43.4(\mathrm{CH}), 58.1(\mathrm{CH}), 183.3(\mathrm{C}=\mathrm{O})$. HRMS (ESI): Calcd. for $\left[\mathrm{C}_{7} \mathrm{H}_{13} \mathrm{NO}_{2}+\mathrm{H}\right]^{+}: 144.1025$. Found: 144.1024 .

\section{Acknowledgements}

CNRS is acknowledged for financial support (grant to M. F.)

\section{References}

1. (a) Kiss, L.; Fülöp, F. Synlett 2010, 1302. (b) Kiss, L.; Forró, E.; Fülöp, F. In Amino Acids, Peptides and Proteins in Organic Chemistry; Hughes, A. B. Ed.; Wiley-VCH: Weinheim, 2009; Vol. 1, pp 367-409. (c) Csende, F.; Fülöp, F.; Stájer, G. Curr. Org. Synth. 2008, 5, 173. (d) Juaristi, E.; Soloshonok, V. A. Eds. Enantioselective Synthesis of $\beta$-Amino Acids; 2nd Edn.; Wiley-VCH: Weinheim, 2005. (e) Miller, J. A.; Nguyen, S. T. Mini-Rev. Org. Chem. 2005, 2, 343. (e) Palko, M.; Kiss, L.; Fülöp, F. Curr. Med. Chem. 2005, 12, 3063. (f) Fülöp, F. Chem. Rev. 2001, 101, 2181.

2. (a) Fülöp, F.; Martinek, T. A.; Tóth, K. G. Chem. Soc. Rev. 2006, 35, 323. (b) Kuhl, A.; Hahn, M. G.; Dumic, M.; Mittendorf, J. Amino Acids 2005, 29, 89.

3. Leading references in this area: (a) Seebach, D.; Gardiner, J. Acc. Chem. Res. 2008, 41, 1366. (b) Horne, W. S.; Gellman, S. H. Acc. Chem. Res. 2008, 41, 1399. (c) Hecht, S.; Huc, I. Eds.; Foldamers: Structure, Properties and Applications; Wiley-VCH: Weinheim, 2007. (d) Cheng, R. P.; Gellman, S. H.; DeGrado, W. F. Chem. Rev. 2001, 101, 3219.

4. (a) Appella, D. H.; Christianson, L. A.; Karle, I. L.; Powell, D. R.; Gellman, S. H. J. Am. Chem. Soc. 1999, 121, 6206. (b) Hetényi, A.; Mándity, I. M.; Martinek, T. A.; Tóth, G. K.; Fülöp, F. J. Am. Chem. Soc. 2005, 127, 547. 
5. Appella, D. H.; Christianson, L. A.; Klein, D. A.; Richards, M. R.; Powell, D. R.; Gellman, S. H. J. Am. Chem. Soc. 1999, 121, 7574.

6. Fernandes, C.; Faure, S.; Pereira, E.; Théry, V.; Declerck, V.; Guillot, R.; Aitken, D. J. Org. Lett., 2010, 12, 3606.

7. Hetényi, A.; Szakonyi, Z.; Mándity, I. M.; Szolnoki, É.; Tóth, G. K.; Martinek, T. A.; Fülöp, F. Chem. Commun. 2009, 177.

8. (a) Lukaszuk, A.; Demaegdt, H.; Szemenyei, E.; Tóth, G.; Tymecka, D.; Misicka, A.; Karoyan, P.; Vanderheyden, P.; Vauquelin, G.; Tourwé, D. J. Med. Chem., 2008, 51, 2291. (b) Price, J. L.; Horne, W. S.; Gellman, S. H. J. Am. Chem. Soc. 2007, 129, 6376. (c) Coffey, P. E.; Drauz, K.-H.; Roberts, S. M.; Skidmore, J.; Smith, J. A. Chem. Commun. 2001, 2330. (d) Seebach, D.; Abele, S.; Gademann, K.; Guichard, G.; Hintermann, T.; Jaun, B.; Matthews, J. L.; Schreiber, J. V.; Oberer, L.; Hommel, U.; Widmer, H. Helv. Chim. Acta 1998, 81, 932 .

9. (a) Lengyel, G. A.; Frank, R. C.; Horne W. S. J. Am. Chem. Soc. 2011, 133, 4246. (b) Korendovych, I. V.; Kim, Y. H.; Ryan, A. H.; Lear, J. D.; DeGrado, W. F.; Shandler, S. J. Org. Lett. 2010, 12, 5142. (c) Bautista, A. D.; Appelbaum, J. S.; Craig, C. J.; Michel, J.; Schepartz, A. J. Am. Chem. Soc. 2010, 132, 2904. (d) Mathad, R. M.; Gessier, F.; Seebach, D.; Jaun, B. Helv. Chim. Acta 2005, 88, 266. (e) Glättli, A.; Seebach, D.; van Gunsteren, W. F. Helv. Chim. Acta 2004, 87, 2487. (f) Raguse, T. L.; Lai, J. R.; Gellman, S. H. Helv. Chim. Acta 2002, 85, 4154.

10. (a) Declerck, V.; Aitken, D. J.; Amino Acids, 2011, 41, 587. (b) Fernandes, C.; Pereira, E.; Faure, S.; Aitken, D. J. J. Org. Chem. 2009, 74, 3217. (c) Fernandes, C.; Gauzy, C.; Yang, Y.; Roy, O.; Pereira, E.; Faure, S.; Aitken, D. J. Synthesis 2007, 2222. (d) Bolm, C.; Schiffers, I.; Atodiresei, I.; Hackenberger, C. P. R. Tetrahedron:Asymmetry 2003, 14, 3455. (e) Martín-Vilà, M.; Muray, E.; Aguado, G. P.; Alvarez-Larena, A.; Branchadell, V.; Minguillón, C.; Giralt, E.; Ortuño,R. M. Tetrahedron: Asymmetry 2000, 11, 3569.

11. (a) Brannock, K. C.; Bell, A.; Burpitt, R. D.; Kelly C. A. J. Org. Chem. 1964, 29, 801. (b) Brannock, K. C.; Bell, A.; Burpitt, R. D.; Kelly C. A. J. Org. Chem. 1961, 26, 625.

12. (a) Dowling, M. S.; Vanderwal, C. D. J. Org. Chem. 2010, 75, 6908. (b) Kitayama, T.; Kawauchi, T.; Ueda, N.; Kniep, C. S.; Shin, W. S.; Padias, A. B.; Hall, Jr., H. K. Macromolecules, 2002, 35, 1591. (c) Shimada, S.; Saigo, K.; Nakamura, H.; Hasegawa, M. Chem. Lett. 1991, 1149. (d) I. Fleming, M. Rowley Tetrahedron 1986, 42, 3181. (e) Agosta, W. C.; Herron D. K. J. Org. Chem. 1969, 34, 2782.

13. Reviews: (a) Juaristi, J.; García-Barradas, O. in Enantioselective Synthesis of $\beta$-Amino Acids; Juaristi, E., Ed., Wiley-VCH: Weinheim, 1997; pp 139-150. (b) Vicaro, J. L.; Badía, D.; Carrillo, L.; Etxebarria, J.; Reyes, E.; Ruiz, N. Org. Prep. Proced. Int. 2005, 37, 513.

14. Review: Davies, S. G.; Smith, A. D.; Price, P. D. Tetrahedron: Asymmetry 2005, 16, 2833.

15. Davies, S. G.; Ichihara, O.; Lenoir, I.; Walters, I. A. S. J. Chem. Soc., Perkin Trans. 1 1994, 1411. 
16. (a) Abraham, E.; Davies, S. G.; Docherty, A. J.; Ling, K. B.; Roberts, P. M.; Russell, A. J.; Thomson, J. E.; Toms, S. M. Tetrahedron: Asymmetry 2008, 19, 1356. (b) Davies, S. G.; Garner, A. C.; Long, M. J. C.; Smith, A. D.; Sweet, M. J.; Withey, J. M. Org. Biomol. Chem. 2004, 2, 3355. (c) Bunnage, M. E.; Davies, S. G.; Parkin, R. M.; Roberts, P. M.; Smith, A. D.; Withey, J. M. Org. Biomol. Chem. 2004, 2, 3337.

17. Davies, S. G.; Durbin, M J.; Hartman, S. J. S.; Matsuno, A.; Roberts, P. M.; Russell, A. J.; Smith, A. D.; Thomson, J. E.; Toms, S. M. Tetrahedron: Asymmetry 2008, 19, 2870.

18. Bunnage, M. E.; Davies, S. G.; Roberts, P. M.; Smith, A. D.; Withey, J. M. Org. Biomol. Chem. 2004, 2, 2763.

19. Davies, S. G.; Garrido, N. M.; Kruchinin, D.; Ichihara, O.; Kotchie, L. J.; Price, P. D.; PriceMortimer, A. J.; Russell, A. J.; Smith, A. D. Tetrahedron: Asymmetry 2006, 17, 1793.

20. Benzing, E. Angew. Chem. 1959, 71, 521.

21. Costello, J. F.; Davies, S. G.; Ichihara, O. Tetrahedron: Asymmetry 1994, 5, 1999.

22. Aitken, D. J.; Gauzy, C.; Pereira, E. Tetrahedron Lett. 2004, 45, 2359. 